\title{
Error analysis of economic terms in the work of indonesian novice translation
}

\author{
Indah Sari ${ }^{1}$ \\ Deakin University \\ Burwood Campus $\cdot$ Melbourne $\cdot$ Australia
}

ABSTRACT

There is a greater demand for a wider range of translation services that increasingly involve scientific, commercial, legal, or technical documents. Translation is no longer limited to literary works which have historically been the main focus of the translation industry in Indonesia. As it is believed that university is the best place for translator training (Bernardini, 2004; Maia, 2012), there have been attempts to put legal and economic translation into the curriculum with the premise that students should be exposed to different types of text to ensure that the materials used in translation classes are relevant to market needs (Kelly, 2000; Heidari and Mowlaie, 2016) However, translating business texts is quite challenging for students because it requires knowledge of text type and genre differences in the SL and TL, and the awareness of the relationship between context and register in terms of field, mode, and tenor are vital for the translator (Beeby, 2000). This paper discusses errors produced by Indonesian novice translators in translating terminology in business texts. The samples used in this study were produced by students at the English Department of Politeknik Negeri Padang in West Sumatra, Indonesia. The institution is a vocational college that trains students in practical competencies, including to work as professional translators. The aim of this paper is to identify the strategies used by students in solving translation problems in an effort to better understand the issues faced in the field of translation in Indonesia.

Keywords: errors, translation, economic, terminology

\section{INTRODUCTION}

Translation was officially introduced in Indonesia in 1974 through the establishment of Himpunan Penerjemah Indonesia (Association of Indonesian Translators) in Jakarta. This association was intended to introduce translation and translators as a profession in Indonesia society as well as to assist its members to find employment. The association was inactive for several years, until the 2000s when a new head created a new focus on improving translator quality. Prior to this, translation training in Indonesia entered the spotlight in 1992 when Indonesia hosted a conference of the Non-Aligned Movement which required more than 5000 translators and interpreters working in English and Indonesian. The event raised awareness of the role of translators. For this reason, Fakultas Sastra Universitas Indonesia set up a translator training program at this time as part of its language center (Machali, 2009).

Nonetheless, the development of translation in Indonesia was still slow. This profession tended to be unacknowledged and lacked respect. Translation was considered to be easy and unimportant due to a common assumption that anyone who could speak a foreign language could translate. Any translation services needed by government or private institutions was provided by their staff who could speak English or who had graduated 
from an English Department. They were reluctant to hire professional translators and did not consider the quality of the translation produced.

Even though it has been difficult, the profession of translator has gradually gained prominence due to increased demand for numbers and quality of translation. For this reason, some universities in Indonesia have started to offer translation programs. While many universities still include translation in their language programs, several universities offer it as a separate discipline. Originally, these courses were offered at the postgraduate level. Now, a few universities also offer translation at the diploma and bachelor's degree level. However, translation education in Indonesia is still in its infancy and has no clear national guidelines or direction. There is currently no collaboration between training institutions and professional associations or the industry in Indonesia.

The increasing demand for translation is the result of Indonesia's attempts to expand and maintain an international network in the economic and other sectors. Both government and private institutions are trying to attract foreign investment and expand international trade (Otto and Sentena, 2015; Otto and Rachman, 2016). For this reason, documents such as contracts, agreements, financial reports, websites, and international correspondence need to be translated from English into Indonesian and vice versa. As a result, business translation has been one of the main focuses in translation education.

\section{REVIEW OF LITERATURE}

Business translation is considered to be specialized translation because it uses language for distinct to the field. It is mainly characterized by extensive use of terminology and the subjects discussed are specific. Scholars agree that this type of translation requires extra-linguistic competence which includes subject matter knowledge, and specialized information. Elthess (2000, p.103) stresses that: "a good command of language is not sufficient without extra-linguistic competence." Anderman and Rogers (2000, p.66) emphasize that "language knowledge is only prerequisite not automatic qualification for translation. Possession of subject matter knowledge specialized in the relevant field is really important." Chiper (2002) also notes that this type of translation requires not only foreign language proficiency but also adequate terminological knowledge. Scholars agree that terminological competence is significant in business translation. According to Martinez and Faber (2009, p.92), "terminological sub-competence does not refer to the acquisition of a list of terms, but rather to the ability of the translator to acquire the knowledge represented by these terms."

Adab (2000) notes that novice translators usually have not acquired sufficient L2 socio-cultural experience and language competence and tend to make decisions based on what they know of comparative and contrastive linguistics. MacKenzie (2004) adds that the problem often lies in students having an inadequate understanding of the source text due to a lack of information and terminological or linguistic knowledge. He suggests this problem might be addressed by research and tools for research, consultation with the author, dictionaries, or recourse to subject and language experts. Using such resources, Giles (2009) notes that there is no reason that insufficient command of the source language should occur even though students do not have a maximum level of language competence.

In the Indonesian context, there can be no doubt that students lack this understanding of the context and its conventions. While exposure to English is high, both through formal education as well as on the internet and television, language training is not rigorous and tends to be shallow. This rarely can provide the depth of linguistic competence, much less contextual competence, required for a satisfactory translation. For this reason, 
a consideration of the errors made by students is important and will have practical implications in allowing more effective training that fills the gaps in student knowledge, resulting in enhanced competency.

\section{Data}

The data for this study was produced by students at the English Department of Politeknik Negeri Padang which was established in 2009. The institution is a vocational school that trains students in practical competencies, including translation. English is taught as a support for a variety of professions that include administrative work, tourism, business, and others. There are at present no standard guidelines for teaching at the polytechnic level in Indonesia in relation to curriculum and the competencies offered. For example, the English Department of Politeknik Negeri Sriwijaya focuses on language needs related to event management and other management fields, while Politeknik Negeri Bandung focuses on business English. The competencies covered by each of these programs overlaps with the business administration training at their institutions. At Politeknik Negeri Padang, which is the source of data here, the English department has begun to identify translation as one of its main competences because of market demand. It is now one of the few Indonesian colleges that includes translation competence in its curriculum. The program requires six semesters, or three years, and is characterized as a diploma program, where students graduate with a Diploma of English.

\section{Terminological errors}

Business translation has become one of the main focuses of translation education. However, it is not easy to translate business texts because of the specialized nature of the material that requires specific treatment. One of the biggest problems for Indonesian students is dealing with terminology because of the need to capture the specific contextual meaning and correctly choose an equivalent in the target language. Some examples of terminological errors made by translation students at Politeknik Negeri Padang include:

Target Text: Pembagian di PayPal jatuh lebih dari 12\% di pasar perdagangan, sedangkan pembagian di eBay meningkat lebih dari $8 \%$.

Source Text: Shares in PayPal fell more than $12 \%$ in aftermarket trading, while shares in eBay rose more than $8 \%$.

The student used the word pembagian to express the English word "shares," which in this text refers to shares of stock. Pembagian, however, is the ordinary Indonesian word used to mean "the process or result of dividing." It is not used to refer to "shares" in the sense of stock; instead the specialized term saham should be used. Also, the student translator did not recognize the term "aftermarket trading" in English which refers to electronic trade in shares that takes place after the stock markets close. Indonesian does not have a term for this, and the English term "aftermarket" or "after hours" is normally used. Therefore, a correct translation of this terms would be "perdagangan aftermarket" or "perdagangan after hours." Again, the omission reflects the student translator's lack of familiarity with business terminology, but the deletion results in a significant loss of information in the translation as compared to the original.

(2) Target Text: Pendapatan Apple turun hampir $8 \%$ pada tahun berikutnya dan diperkirakan akan meningkat dan diperkirakan akan meningkat kurang dari $6 \%$ untuk pendapatan negara yang berakhir pada tanggal 30 September.

Source Text: Apple's revenue slipped nearly $8 \%$ the following year and is expected to rise less than $6 \%$ for the fiscal year ending Sept 30. 
Pendapatan in Indonesian means "income, revenue." The phrase pendapatan negara means "national revenues." Interestingly, the word pendapatan was correctly used by this translator to express the phrase "Apple's revenue" in this text. The translator was apparently not familiar with the term tahun anggaran, which is the correct translation of "fiscal year." Tahun fiskal would be potentially acceptable but uses an English loan word. Again, this suggests a lack of familiarity with business terminology.

(3) Target Text: ...melampaui angka di U.S. pedagang toko tersisa setengah sejak mengisi 11 cabang yang bangkrut di bulan september.

Source Text: cutting the number of U.S. retail stores roughly in half since its chapter 11 bankruptcy filing in September.

The term "Chapter 11" here refers to a specific section of the United States' Bankruptcy Code. This set meaning was missed by the student translator who apparently also did not recognize the word "chapter," which is incorrectly translated as $b a b$ in Indonesian. Instead, this translator used the word cabang, "branch," suggesting he or she did not understand the meaning of the text. It should be noted that this example contains other errors in translation that suggest a lack of comprehension.

(4) Target Text: Tahun ini, pembatasan biaya bisa untuk menyalahkan kinerja mereka yang tidak bersemangat dalam campur tangan bank central di pasar.

Source Text: For years, hedge funds have been able to blame their lackluster performance on central bank interference in markets.

This student translator mistranslated the business term "hedge fund" as pembatasan biaya because he or she apparently did not recognize this as a set phrase and attempted to convey the meaning of the individual words. Pembatasan means "limitation" while biaya means "cost, fee." In fact, the term "hedge fund" should be translated as dana lindung nilai, a compound term created to convey the intent of hedge funds, namely to generate profit using borrowed funds or credit. This highly specific term might well be unfamiliar to a student translator but, since resources exist where such terms can be looked up, this individual apparently did not use one of these discipline specific dictionaries.

(5) Target Text: Sebelum Snap menuju publik, perkembangannya sangat cepat sebagai seorang pemula dan keterlibatan yang tinggi di kalanggan pengguna - terutama pada remaja dan 20 investor yang kagum dan pesaing yang ketakutan.

Source Text: Before Snap went public, its fast growth as a startup and high engagement among users --especially those in their teens and 20s--wowed investors and scared competitors.

In this example, the student translator attempted to translate the two terms, "go public" and "start up," literally. This failed to convey the meaning of the original text and would create confusion for a reader in Indonesian. In fact, both these English terms are used in writing about business in Indonesia, as there are no exact equivalents. This shows a lack of knowledge of business usage in Indonesian. However, the translation contains other errors, including word order, that suggests the student did not understand the meaning of the text

(6) Target Text: The victim give claim but Alvin think no one that finally can pay suit with the rule from police.

Source Text: Korban pun mengajukan klaim tetapi menurut Alvin tak satu pun yang akhirnya dibayarkan sesuai dengan ketentuan dalam polis.

The student translator used the term "give claim" to express mengajukan klaim. This is an incorrect idiom that would be very difficult for an English speaker to correctly interpret. Mengajukan klaim refers to a request made by a client to an insurance company to pay following an insured event. In English, this action is referred to as "filing a claim." This shows the student lacks knowledge of this English business idiom. The student translator made another error, translating the term polis as "police," which does not make sense in this context It seems that the student incorrectly identified that polis as a loan word derived from the English word "police," which to Indonesian speakers seem to be pronounced similarly. Polis is, in fact, the Indonesian form that means "policy" in the context of insurance because 
the student did not know this and did not look it up, he or she had to force the meaning of the preceding phrase to accommodate "police," despite the difficulty of understanding what the sentence then meant.

(7) Target Text: Sinar Mas agribusiness and food signatured note of understanding (MOU) with the Canaan Enterprise Company Ltd (Canaan).

Source Text: Sinar Mas Agribusiness and Food menandatangani Nota Kesepahaman (MOU) dengan Canaan Enterprise Company Ltd (Canaan).

The student translator attempted to translate the term Nota Kesepahaman literally as "note of understanding." He or she was not aware that the term MoU in brackets to assist readers by indicating that nota kesepahaman means MOU. The term "memorandum of understanding" has been used in Indonesian in the past. However, instead of using the full term, Indonesian used to refer to this type of agreement as MoU before the Indonesian term was the term was rarely spelled out, and most Indonesians would only recognize MOU without considering its expansion. Therefore, the correct translation here would be "memorandum of understanding." Again, the student did not possess an adequate understanding of business terms in either Indonesian or English.

(8) Target Text: Same with, Pandji Harsanto, the independent finances draftsman, said, so that your trip can still fun...

Source Text: Senada, Pandji Harsanto, perencana keuangan independen, mengatakan, supaya pelesiran Anda bisa tetap fun...

The student translator attempted to translate the term perencana keuangan independen literally as "the independent finances draftsman." In addition to the problematic use of the term draftsman that refers to a specific profession outside of the business context, the students failed to grasp the overall meaning of the term which should have been translated as "independent financial planner." While this role is new in Indonesia, there are ample opportunities to see it in context in business news as well as resources available to students to look up standard translations of titles and professions.

(9) Target Text: The Expedition Company PT Tiki Jalur Nugraha Ekakurir or JNE is aiming for 30\%-40\% of shipping volume growths in Manado in this year.

Source Text: Perusahaan ekspedisi PT Tiki Jalur Nugraha Ekakurir atau JNE membidik pertumbuhan volume pengiriman sebesar 30\%-40\% di Manado sepanjang tahun ini.

The student translator attempted to translate the term perusahaan ekspedisi as "expedition company." Although the English term "expedition" and the Indonesian term ekspedisi seem similar, they have different meanings in the business context that relate to the rules for incorporation of lean words in standard Indonesian. Expedisi derives from "expedite," which is not idiomatic in English in this usage but reflects an Indonesian type of usage that is not related to native speaker use. In fact, the correct translation should be "shipping company." This error would cause considerable problems for an English speaker.

(10) Target text: ... and most or 85 percent is UKM with the largest is in electronic, accessories and fashion.

Source Text: .......dan sebagai besar atau sekitar 85 persen adalah UKM dengan penjualan terbesar ada pada barang elektronik, aksesoris gawai, dan fashion.

In this example, the student translator did not correctly handle the terms UKM and gawai. UKM was left untranslated, while gawai was omitted from the translation entirely. UKM is an Indonesian abbreviation of usaha kecil menengah, which should have been translated as "Small and Medium-sized Enterprises" or SME. The student was apparently unaware that a term comparable to the Indonesian existed in English. The omission of the term gawai changes the meaning of the text because the student's translation gives the impression that among the items of interest is "accessories" which, when used alone, generally refers to items of apparent that complete an outfit of clothing. In the Indonesian text, gawai is a new term that means accessories for mobile telephones, computers, and the like, so aksesoris gawai, should have been translated as "electronic accessories."

(11) Target text: Satu lagi orang inggris mengikat restoran dan hutang ekspansi menjadi luas. 
Source Text: Other British restaurant chains are struggling as a debt-fueled expansion boom pops

This translator incorrectly used the word mengikat "chain (v)" because of a misunderstanding of the term "restaurant chain." "Chain" in this context refers to a number of restaurants run under the same name by a parent company. This kind of business arrangement is usually conveyed by use of the term jaringan, "network." It should be noted that this sample contains several other errors, including in word order in the Indonesian, suggesting that the translator had difficulty understanding the text as a whole and was uncertain what the text meant.

(12) Target text: Wage structures and scales shall be attached at registration, extention, or renewal of the Joint Working Reform or Company Regulations.

Source Text: Struktur dan skala upah harus dilampirkan saat pendaftaran, perpanjangan, atau pembaharuan Perjanjian Kerja Bersama (PKB) atau Peraturan Perusahaan.

In this example, the student translator used the term "renewal of the joint working reform" to express pembaharuan perjanjian kerja bersama. However, the terms are not equivalent. The term perjanjian kerja bersama refers to an agreement to make standard working regulation by several parties such as companies and the government. On the other hand, the English term "Joint working agreement" refers to an agreement between some companies to work together. Therefore, it should have been translated as "collective labour agreement" or "collective employment agreement".

(13) Target text: Modern store In network Lazada will to confess government arrangement hooked special tax hold for bussines electronic doer or E-commerce the draft publish in time this near.

Source Text: Toko modern dalam jaringan (daring) Lazada mengaku akan mengikuti aturan pemerintah terkait pemberlakuan pajak khusus bagi pelaku bisnis elektronik atau e-commerce yang rencananya terbit dalam waktu dekat ini.

The student translator translated the term dalam jaringan (daring) literally into the term "in network" which does not fit for e-commerce context. The correct term should be on line. Meanwhile, "in network" is English term for insurance which refers to providers or health care facilities that are parts of a health plan's network of providers. Actually, Indonesian normally used on line term as the loan word. However, Indonesian government decided to introduce Indonesian terms to avoid too many loan words in Indonesia language. Although dalam jaringan (daring) is widely used now, some people still use the loan words. This mistake shows that the student translator did not recognize and understand the concept of business term in Indonesia language.

(14) Target text: PayPal Holdings Inc. kehilangan potongan bisnis dari salah satu sumber terbesar kostumer.

Source Text: PayPal Holdings Inc. is losing a chunk of the business of one of its biggest sources of customers.

The original text uses the word "chunk" to mean "part," with the suggestion that the part in question is significant. This figurative usage is not reflected in the translator's choice of the word potongan, which does mean "part" but is not generally used in this context in the meaning in question. The root of term in Indonesian, potong, is the verb "cut" as with a knife. In this context, sebagian, which means "a part," would be a more appropriate choice in terms of tome as well as fit with the business domain. Instead of using the loan word konsumen or the Indonesian term pelanggan, the student translator converted the word "customers" into kostumer to refer to clients or buyers. While Indonesian does use a large number of loan words, especially from English, accepted terms have been standardized by the national language planning agency, Badan Bahasa Nasional, and appear in dictionaries and specialist references for various fields. The word kostumer is not an acceptable translation in this sense and would not be known by the average Indonesian speaker.

(15) Target Text: ... yang mana pengumpulan rumah amal mengatakan tidak akan datang sampai awal tahun 2019.

Source Text: ...which the home-sharing company said won't come until 2019 at the earliest.]

The student translator used the term pengumpulan rumah amal to express "home-sharing company" which is incorrect. Pengumpulan rumah amal means "the collection of accumulation of houses obtained by charity or donation," while, in fact, "home-sharing company" in the original text refers to businesses which offer short-term Revista de Lenguas para Fines Específicos 26.1 ISSN : 2340-8561 
rental accommodation, such as Airbnb. The correct term should be perusahaan penginapan rumahan or the English term "home-sharing company" could be used because this business concept is foreign to Indonesian society. The student translator did not recognize the term exactly because this kind of company is not familiar in Indonesia. The choice of the translator to use a word-for-word equivalent resulted in an incomprehensible and misleading phrase in Indonesia.

\section{Factors in terminology problems}

Finding the most equivalent term can be very challenging for Indonesian translation students. As novices, they still lack skill and experience in translating specialized texts with higher levels of difficulty. Some of the factors that relate to terminology errors include:

\subsection{Proficiency in source and target languages}

In this study, data included student translation from Indonesian into English as well as the more expected translation from English into Indonesian. Translators in Indonesia are supposed to be able to translate in both directions, even though this is challenging even for the most experienced individuals. While clients in Indonesia prefer to hire Indonesian translators because of cost (despite a lack of proficiency), it is the case that it is very difficult to find qualified English-speaking translators who are competent to translate into Indonesian.

An additional factor that must be considered in Indonesia specifically is the fact that very few Indonesians speak the national language as a first language. The majority of the population speaks one of 700 indigenous local languages first and only begins to use Indonesian when they enter school. While Indonesian is used almost exclusively in public contexts and all official ones, most daily interaction is in a local language of the region in question. As a result, many people do not have very high proficiency in Indonesian, even if they graduated from high school and are attending college. The Association of Indonesian Translators recognizes this issue and, since 2017, has required that its members demonstrate proficiency in Indonesian in order to be certified.

This complex language context also contributes to the recognized lack of facility in English, despite the fact that it has long been the most widely taught foreign language in Indonesia. The need to master Indonesian, which is not always reinforced in daily interaction, necessarily takes precedence, and the problem is compounded by the fact that the systems of English and Indonesian are extremely different. In addition, the fact that Englishlanguage culture is extremely popular in Indonesia is leading to what some observers describe as a dialect of Indonesian usage of English that is associated with Indonesian conventions and has little resemblance to the usage of native speakers (see Lauder, 2010).

In the business environment specifically, it is still the case that Indonesian uses a range of loan words that are treated differently. Some, like "after hours trading" are used in their original form. Others have been adapted to Indonesian orthographic needs as well as pronunciation, such as polis. Increasingly, however, Indonesian roots are being extended to cover terms that used to be used in loan form. An example of this is the use of gawai to replace "gadget" the incorrectly used English term that has been used to mean "electronic accessory" in Indonesian. It requires considerable experience to become aware of current usage, and students generally do not possess this awareness or the motivation to obtain it. While the use of terminology in Indonesian can be gained from business reports in the standard media, it is unusual for younger Indonesians to read much (BPS, 2018), even if it directly relevant to their career objectives. 


\subsection{Dictionaries}

The use of a dictionary by novice translators should be taken as given. There are many dictionaries of English available to students in Indonesia, both in hard copy and online, but these are largely monolingual, and students tend to have difficulty understanding the definitions and explanation. There is no official Indonesian-English or English-Indonesian dictionary produced by the national language planning body. The bilingual dictionaries that are available are old and very incomplete. Nonetheless, students tend to prefer them because they are easier to use.

The available bilingual dictionaries provide only a single word equivalents without explanation of range of use and specific contexts. As a result, students tend to assume that choosing an equivalent will result in a correct translation and tend to overlook both range of use and context-specific conventions. Again, dictionaries of business terms are available, but students must be able to understand the English language definitions. A lack of appropriate dictionary resources for Indonesian is a serious impediment to translation at all levels but is especially significant for students. It is worth noting that Malaysia, whose national language is linguistically related to Indonesian, has expended enormous effort into producing dictionaries of all kinds for standard Malay. Unfortunately, these resources do not reflect Indonesian usage, which is very different, but suggest a model which Indonesian language planners might consider in addressing the lack of similar resources in the language of Indonesia.

\subsection{Online resources such as Google Translate}

Not surprisingly, Indonesian student translators make heavy use of the internet, which is very popular in Indonesia anyway for entertainment purposes and for social media use (see Yuniarni, 2018). For this reason, Google Translate is often their first and only attempt to seek assistance with translation.

As is the case for many lesser known languages, Google Translate is mostly useful for speakers who have a high-level facility in both Indonesian and English and may be having difficulty recalling a word or who can use it as a prompt. The application is not very accurate in translating phrase or longer pieces of text and is a poor resource for translation that is highly context-specific. Student translators are rarely aware of such issues and are mostly motivated by the desire to save time and the ease of using a resource that is available on a smart phone. There can be little doubt that some of the errors they make are due to overreliance on this type of aid and their reluctance to use more complete recourses that are more time consuming and less convenient.

\subsection{Translation strategy}

The novice translators in this study tend to use literal translation as the strategy to solve most translation problem they found especially when encountering unfamiliar words or terms. An example of this is the use of "in network" which is a literal translation of "dalam jaringan", an Indonesian term to express "the condition connected to computer or internet network" and should have been translated as "online". Moreover, when the students do not have any idea of what the literal translation of the specific term, they rely on transference strategy. In this strategy, they will keep the source word or leave it untranslated without giving any explanation at all. For example, when the students decide not to translate "UKM" (an Indonesian abbreviation of Usaha Kecil Menengah) which should have been translated as "Small and Medium-sized Enterprises" or SME. Apparently, they used those strategies because the students have lack of knowledge on other translation strategies. Despite of the errors caused by those strategies, the students find them to be the easiest and fastest way in doing the translation job. 


\subsection{Subject matter knowledge}

Finally, translation is not about the language itself, it is about understanding the message in order to be able to transfer the message to the target readers. Nonetheless, it seems that these student translators consider that translation is simply an activity to replace the source language with the target language which can be seen from the resources they accessed such as dictionary and google translate as well as the strategy they used. As the result, the translation tends to be unnatural and unsuitable with the context even the messages are not successfully conveyed. The mistake they made shows that they did not have sufficient business terminological competence. They did not have the ability to recognize business terminology, as well as its use, from ordinary words. Lack of terminological competence is the result of lack of subject matter knowledge which is necessarily required in translating a specialized text like business text. An example of this is by translating the term chapter 11 bankruptcy as " $b a b$ " which is chapter in a book. It requires awareness that there is a specific concept and definition behind this term.

Some translators may limit themselves to accept translation job within their specification only. Nonetheless, it is also common for a translator, especially in Indonesia, to translate text from various disciplines. It of course requires encyclopedic knowledge means that he should have knowledge on subject other than his expertise. However, this type of knowledge is not instantly acquired however obtained through a very long reading habit. Unfortunately, in their research study, Miller and McKenna (2016) even put Indonesia as number 60 from 61 most illiterate countries in the world based on its society's literacy level. Low reading habit in Indonesia has impacted to the society knowledge. According to a study conducted by Indonesian Institute of Sciences (LIPI, 2015), 54\% of Indonesian has low knowledge on science or even technology issue.

No doubt that the student translators do not have enough knowledge on business and economic because it is not their area of expertise and they are not exposed to this field. Even if so, they can search for knowledge on business context by accessing some related articles or websites using internet. Unfortunately, they do not have any skill to find the information needed even though they are equipped with technological devices.

\section{Conclusion}

The demand for translation into and from English is increasing in Indonesia and reflects the nature of the business environment. There is a commensurate demand for skilled translators who, by necessity, must be able to translate in both directions between these two languages. Indonesian students who aspire to work as professional translators come to training programs, such as the one at Politeknik Negeri Padang, at a disadvantage. Despite considerable formal and informal exposure to English, Indonesian students rarely have usable mastery of natural, authentic English and tend to have little awareness of style, dialect, or specialized usage associated with a given discipline or area of expertise. In addition, many do not have native facility in Indonesian, despite it being the national language and language of instruction at all levels of education. As a result, they are generally unprepared for the demands of translation, as the errors discussed above indicate.

For formal training programs in translation, which are in demand and whose graduates are expected to meet the needs of a growing industry, it is imperative to try to address specific problems that entering students tend to have. The first area of concern is language mastery. It is clear that students still require training to improve language mastery and that this training must focus on authentic usage that is more coherent in terms of linguistic features as well as sociocultural elements of language use. However, they also lack discipline specific knowledge 
in both Indonesian and English and, for this reason, need to read much more in both languages. This probably should be incorporated into the curriculum as students are unlikely to engage in reading as a way to improve their mastery unless it is associated with their formal progress in the course. They also need specific instruction in using reference materials and strategies for finding information online that can support their translation. If left to their own devices, they gravitate toward the easiest, fastest alternative which, in this case, is rarely adequate and often inaccurate. Finally, they need specific strategies that may help them when confronted by unfamiliar material and will suggest how to proceed. This should be taught as part of translation theory studies but, in practice, is often omitted.

These and other innovations in curriculum and teaching practice are vital in translation programs in Indonesia if graduates to be able to fill the positions available for professional translators in the current workforce. More important, a change in direction in the curriculum and approach used to train translators at the college level will better equip students to move into the workforce and then progress through their career by giving them the tools they will need to develop their own skills after completing their program and to continue to grow and expand as professional translators.

\section{About the author}

Indah Sari is a PhD student at Faculty of Arts and Education Deakin University Australia. Her research is about error analysis on the work of Indonesian novice translation. She obtained her master's degree in applied Linguistics from Universitas Indonesia, Indonesia. Her master thesis discussed annotated translation in a popular psychology book. Currently, she works as a lecturer at Politeknik Negeri Padang, Indonesia where she teaches translation for Diploma III students. Besides that, she also joins The Association of Indonesian Translators since 2014.

\section{References}

Adab, B. (2000). Evaluating translation competence. In C. Schaffner \& B. Adab (Eds.), Developing translation competence (pp.215229). Amsterdam: John Benjamins.

Anderman, G \& Rogers, M. (2000). Translator training between academia and profession: A European perspective. In C. Schaffner \& B. Adab (Eds.), Developing translation competence (pp.63-76). Amsterdam: John Benjamins.

Badan Pusat Statistik. (2018). Proporsi Penduduk Berumur 10 Tahun ke Atas yang Membaca Selama Seminggu Terakhir Menurut Provinsi, Jenis Bacaan, dan Tipe Daerah. <https://www.bps.go.id/statictable/2014/08/20/1521/proporsi-penduduk-berumur-10tahun-ke-atas-yang-membaca-selama-seminggu-terakhir-enurut-provinsi-jenis-bacaan-dan-tipe-daerah-2012.html> [12/07/2018].

Beeby, A. (2000). Evaluating the development of translation competence. In C. Schaffner \& B. Adab (Eds.), Developing translation competence (pp.185-198). Amsterdam: John Benjamins. 
Bernardini, S. (2004). The theory behind the practice: Translation training or translator education? In K Malmkjaer (Ed.), Translation in Undergraduate degree programmes (pp. 17-30). Amsterdam: John Benjamins.

Chipper, S. (2002). Business translation. Perspectives: Studies in Translatology, 10(3), 215-233.

Elthes, A. (2000). Reflection on teaching translation from French into Hungarian at the Technical University of Budapest: Towards a function-dependent course typology. In C. Schaffner \& B. Adab (Eds.), Developing translation competence (pp.101-114). Amsterdam: John Benjamins.

Gile, D. (2009). Basic concepts and models for interpreter and translator training. Amsterdam: John Benjamins.

Heidari, E \& Mowlaie, M. (2016). Iranian instructors' practices and criteria for teaching English translation. Theory and Practice in Language Studies, 6(3), 621-630.

Lauder, A. (2010). The Status and Function of English in Indonesian: A Review of Key Factors. Makara, 12(1), 9-20.

Lembaga Ilmu Pengetahuan Indonesia. (2015) Masyarakat kurang paham Iptek. <http://lipi.go.id/berita/single/Masyarakat-Kurang$\underline{\text { Paham-Iptek/11040> }}$ [10/12/2018].

Kelly, D. (2000). Text Selection for Developing Translator Competence: Why Texts From The Tourist Sector Constitute Suitable Material. In C. Schaffner \& B. Adab (Eds.), Developing Translation Competence (pp.157-170). Amsterdam: John Benjamins.

Machali, R. (2009). Pedoman bagi penerjemah: Panduan lengkap bagi Anda yang ingin menjadi penerjemah. Bandung: Kaifa.

MacKenzie, R. (2004). The competencies required by the translator's roles as a professional. In K Malmkjaer (Ed.), Translation in Undergraduate degree programmes (pp. 31-38). Amsterdam: John Benjamins.

Maia, B. (2010). The role of translation theory in the teaching of general and non-literary translation-revisited. In B. LewandowskaTomaszczyk \& M. Thelen (Eds.), Meaning in Translation (pp.437-454). Frankfurt: Peter Lang.

Martinez, S.M \& Faber, P. (2009). Terminological Competence in Translation. Terminology, 15(1), 88-104.

Miller, J.W \& McKenna, M.C. (2016). World Literacy: How Countries Rank and Why It Matters. New York and London: Routledge.

Otto, B \& Rachman, A. (2016). Indonesia opens more big businesses to foreign investment. http://www.wsj.com/articles/indonesiaopens-more-big-businesses-to-foreign-investment-1455185389 [08/12/2016].

Otto, B \& Sentenna, I.M. (2015) Indonesia makes attracting foreign investment a priority. <http://www/wsj.com/articles/indonesiamakes-attracting-foreign-investment-a-priority-1440676597> [08/12/2016].

Yuniarni, S. (2018) Indonesia had 134 M users in 2017: APJII. <http://jakartaglobe.id/business/indonesia-143m-internet-userts-2017apjii> [19/02/2018]. 